\title{
THE ROUTLEDGE COMPANION TO \\ CULTURAL HISTORY IN THE WESTERN WORLD
}

Edited by Alessandro Arcangeli, Jörg Rogge and Hannu Salmi 
First published 2020

by Routledge

2 Park Square, Milton Park, Abingdon, Oxon OX14 4RN

and by Routledge

52 Vanderbilt Avenue, New York, NY 10017

Routledge is an imprint of the Taylor \& Francis Group, an informa business

(C) 2020 selection and editorial matter, Alessandro Arcangeli,

Jörg Rogge and Hannu Salmi; individual chapters, the contributors

The right of Alessandro Arcangeli, Jörg Rogge and Hannu Salmi to be identified as the authors of the editorial material, and of the authors for their individual chapters, has been asserted in accordance with sections

77 and 78 of the Copyright, Designs and Patents Act 1988.

All rights reserved. No part of this book may be reprinted or reproduced or utilised in any form or by any electronic, mechanical, or other means, now known or hereafter invented, including photocopying and recording, or in any information storage or retrieval system, without permission in writing from the publishers.

Trademark notice: Product or corporate names may be trademarks or registered trademarks, and are used only for identification and explanation without intent to infringe.

British Library Cataloguing-in-Publication Data

A catalogue record for this book is available from the British Library

Library of Congress Cataloging-in-Publication Data

A catalog record has been requested for this book

ISBN: 978-1-138-64946-0 (hbk)

ISBN: 978-1-003-08020-6 (ebk)

Typeset in Bembo

by Swales \& Willis Ltd, Exeter, Devon, UK 


\section{CONTENTS}

List of illustrations $\quad i x$

List of contributors $\quad$ xii

Acknowledgements $x x$

General introduction 1

Alessandro Arcangeli, Jörg Rogge and Hannu Salmi

\section{PART 1}

Shaping Western identities, 1250-1500 7

Introduction 9

Jörg Rogge

1 Culture of politics in the Middle Ages: rituals to create and confirm political order

Hermann Kamp

2 Cultures of conflict

Jackson W. Armstrong

3 Material cultures of living: spatiality and everyday life Jan Hirschbiegel and Gabriel Zeilinger

4 Travel, mobility, and culture in Europe

Marianne O’Doherty

5 Cultural encounters and transfer: the case of pious foundations in the Islamicate world

Johannes Pahlitzsch 
6 Practices of communication: literacy, gestures and words research on late medieval communication

Franz-Josef Arlinghaus

7 Making sense of one's life and the world

Marek Tamm

8 Conceiving of medieval identities

Christina Lutter

9 Body, sexuality, and health

Dominik Schuh

10 Contextualizing late medieval emotions

Esther Cohen

PART 2

Europe meets the globe: Western identities in question, 1500-1750

Introduction

Alessandro Arcangeli

11 God's green garden: interactions between humans and the environment

Linnéa Rowlatt

12 Material cultures of living: European attitudes to novelties Raffaella Sarti

13 Reverence, shame and guilt in early modern European cultures Jonas Liliequist

14 Making sense of the world: the creation and transfer of knowledge Hjalmar Fors

15 The self: representations and practices James R. Farr

16 The experience of time Brendan Dooley

17 Written communication in urban spaces: publication, textual materiality and appropriations Antonio Castillo Gómez 
18 Mobility, global interaction and cultural transfers in the age

of exploration

Giuseppe Marcocci

19 Faces of power and conflict

Tomás A. Mantecón

\section{PART 3}

The Western world and the global challenge, from 1750 to the present

Introduction

Hannu Salmi

20 Enlightenment, revolution, and melancholy

Asko Nivala

21 Individualism and emotion in modern Western culture

Peter N. Stearns

22 Health and illness, the self and the body

Willemijn Ruberg

23 Family, home and variations in domestic life

Kirsi Tuohela

24 Natural disasters and modernity

Kyrre Kverndokk

25 Cultures of mobility

Dhan Zunino Singh

26 The cultural life of the senses in modernity

Constance Classen and David Howes

27 Media and mediatization

Pelle Snickars

28 Indigenous and postcolonial cultures

Mita Banerjee

29 Violence and trauma: experiencing the two World Wars Ville Kivimäki 


\section{Contents}

30 The Cold War cultures and beyond Steven Conn

31 The culture of commerce and the global economy 552 Jared Poley

32 Epilogue: cultural history in retrospect 568 Hannu Salmi

Index of names 573 
6

\title{
PRACTICES OF COMMUNICATION
}

\section{Literacy, gestures and words: research on late medieval communication}

\author{
Franz-Josef Arlinghaus
}

\begin{abstract}
Introduction
It goes without saying that understanding communication is a key element of understanding society. However, at a time when the internet and telephone were not invented and even writing was less common than today, would a chapter on 'practices of communication' be a little short? As it turns out, during the centuries we focus on here, people communicated in very refined and highly differentiated ways. The following text not only tries to focus on literacy, orality, messengers and rituals, but also attempts to shed light on how a combination of these elements worked in a given situation.

Rituals are irrational and literacy means rationalization. For a long time, historians have written about how 'the Middle Ages were already quite literate/rational' or looked at the trajectory 'from rituals to rationalization' and the like. In the meantime, the picture has become much more complex. Rituals are increasingly seen as an expression of clever political moves, and charters, books and the reading of texts portrayed as ritualized performances. While dichotomies seem to vanish and teleological narrative is discredited, despite long and intense research efforts, the relationship between rituals, literacy and medieval society is still a story ending with 'to be continued'. However, historical research today knows a lot more about these phenomena than, say, 20 or 30 years ago and, what is more, today we are able to ask very refined questions that, thanks to inquiries during the recent decades, are able to avoid many of the pitfalls and mistakes of the past.

Medieval History, with the auxiliary sciences Diplomatics and Paleography, always took a special interest in writing. However, with McLuhan's The Gutenberg Galaxy of 1962 which, with reference to television, saw 'the end of the age of books' coming (Das Ende des Buchzeitalters was the subtitle of the German edition), ${ }^{1}$ the humanities in general became more and more interested in the phenomenon of literacy. Jack Goody and Walter Ong pushed this even further when arguing that the use of
\end{abstract}


writing would, to make a complex argument very short, change the minds of those who use it. ${ }^{2}$ The same holds true for rituals. As far back as Jacob Grimm's Deutsche Rechtsalterthümer of $1828,{ }^{3}$ Medieval History, especially Medieval Legal History, looked at gestures and performances. However, John L. Austin's How to Do Things with Words (1963) and the studies of Erving Goffman on interaction in everyday life, ${ }^{4}$ to name but two authors, opened up a new approach in terms of rituals.

Nonetheless, it seems that it was not until the 1980s and 1990s that a shift in the perspective on literacy and ritual took place in Medieval History. Whereas at first, historical research proclaimed a strong dichotomy between literacy and ritual, roughly around and after the year 2000, writing in premodern times was increasingly seen as part of (oral) performances and gestures, and sitting orders and the like are now looked at as having their own 'rationality'.

\section{Framing premodern times: new theoretical approaches}

Interestingly enough, the sources upon which the new approach draws are often very well known, but parts of the texts have either been ignored so far or interpreted in quite a different way. For example, a great part of the text of the 'Golden Bull' of 1356, which outlines the election of the German king, describes gestures as well as sitting orders. Older research tended to neglect these paragraphs of the (often called) first German constitution, while precisely these elements are considered most useful in order to understand the way premodern societies function today. ${ }^{5}$ Why is that?

The central issue here is a change of paradigms, which altered the view on this and other well-known texts:

(1) First, gestures, rituals and sitting orders are no longer considered as 'plays' that demonstrate reality to a wider (and illiterate) public. Rather, they themselves are seen as ways of creating reality. In this view, sitting orders, for instance, establish and manifest a hierarchy and an order between those seated, and that is why positions are sometimes defended violently. In other words: rituals do not demonstrate, but create order.

(2) Second, this paradigm is linked to a new way of looking at premodern society as such. Different from today, medieval and early modern society is considered to be a society built on the co-presence of the actors ('Vergesellschaftung unter Anwesenden', 'Präsenzgesellschaft'). ${ }^{6}$ This paradigm places a question mark on the notion of premodern institutions having the same shape as modern and, for instance, emphasizes that the Holy Roman Empire exists mainly in the form of diets and other 'come-together' ${ }^{7}$ Interestingly enough, this concept was mainly developed by historians specializing in the sixteenth and seventeenth centuries. At this point, one may rightly ask why or how, after the enormous spread of literacy during the High and Late Middle Ages and especially after the invention of the printing press, charters, books and writing as such fit into this picture.

(3) What 'status' do media (in the broadest sense of the word) have in premodern times? Since the 1990s especially, scholars emphasize that, in the Middle Ages, words and pictures had the capacity to make those who are absent - whether 
because they are in another place or because they lived in another century appear to be present. ${ }^{8}$ This is due to an almost ontic understanding of signs, a legally binding concept of representation and a perception of pictures as cult images. ${ }^{9}$ This even holds true if one takes into account that the identity of words and objects was questioned, for instance, in the context of the universal controversy of the eleventh and twelfth centuries, and as early as in the ninth and again in the eleventh century, the real presence of Christ in the Eucharist was a matter of debate. ${ }^{10}$

These paradigms, although developed mainly from different points of view on the Middle Ages (historical and sociological approaches for points one and two, literature and cultural theories for point three), do match insofar as they clearly indicate a warning against interpreting medieval forms of communication without taking into account the different cultural and societal 'environment' in which they take place, and to be careful when attributing today's aims and functions to gestures and texts that were performed and written 20 or 30 generations ago. On the other hand, one could ask whether recent research in medieval and literary history does not overstretch this approach, and whether there is a tendency to certain 'medievalism' that portrays the epoch as just the opposite of modernity. And is it not true that medieval empires and cities developed modern forms of administrative techniques, such as written laws, protocols and the like since the early days?

\section{Performing literacy}

Since the inspiring, already-mentioned works of Jack Goody and Walter Ong, literacy was looked at as the technology that paved the way to Western modernity for a long time. Writing seems not only useful in terms of administration, economy and law. More than that, the use of the pen and reading seemed to alter the way people think and look at the world. Since writing with letters instead of pictograms (as in Egypt or China) is considered to lead to a more abstract view on the world, ${ }^{11}$ it is essentially a story of the rise of the West. Elizabeth L. Eisenstein's book about the printing revolution seemed to be designed to complete this picture, ${ }^{12}$ since Ong has already emphasized the importance of that invention, although more occupied with ancient Mesopotamia. ${ }^{13}$

This short sketch is merely designed to illustrate the type of intellectual background medievalists consulted to examine literacy and writing in their epoch of research. With its long-standing tradition of auxiliary sciences, such as Palaeography, Diplomatics and Sigillography, to name but a few, medieval research seemed to be well prepared for a new look at literacy. Michael Clanchy's From Memory to Written Record, first published in 1979 and thoroughly revised for the second edition of 1993, can be considered the ground-breaking study on the effects of literacy in the Middle Ages. The book's table of contents almost reads like a programme or summary of the international medieval research on literacy undertaken during the 1980s and 1990s: the analysis of 'Technology of Writing' (including wax, parchment, rolls and books), 'Preservation and Use of Documents', 'Types' and 'Language of Record', as well as 'Literate and Illiterate', was on the agenda. While at least part of these themes can be 
considered 'classics' of medieval auxiliary sciences, it was (a) the new perspective on these 'classics' and (b) their combination with new themes such as 'Proliferation of Documents', 'Spoken versus the Written Word' and 'Trust in Writing' that framed a new understanding of writing in the Middle Ages.

A number of individuals and research groups (namely in Münster, Freiburg, Utrecht and Zürich) devoted themselves to the theme, ${ }^{14}$ often without being directly inspired by the named book, but quite often with a similar agenda. The overall question in most research projects was how the spread of literacy, especially during the High Middle Ages, ${ }^{15}$ changed the way people organized their everyday lives and how it changed the way people conceptualized the world. With Rosamond McKitterick's book on the use of writing during the eighth and ninth centuries, the approach was tested also for the early Middle Ages. ${ }^{16}$ Practical literacy was considered an everyday tool that helped to organize the political sphere of the rising Italian city communes of the eleventh and twelfth centuries as well as the economic organization of cloisters or late medieval noble households. The consequences of this 'help' went far beyond better administration. If I may simplify: what was once mostly memorized or decided anew in assemblies more and more could be looked up in charters or statutes. Cloisters as well as merchants started to write down their economic transactions, legal contracts, etc. Along with this, groups such as notaries and city scribes played a new and increasingly important role in society. ${ }^{17}$ It seems that, in summary, a new way of communicating gained ground that centred on written records. Writing now played a prominent role in all spheres of everyday life, and this life and even the approach of the people to this life, and thus the idea, changed dramatically. ${ }^{18}$

While Goody, Ong and others ${ }^{19}$ took on a very broad view, suggesting that the use of writing, especially the alphabetic writing of the near east and Europe in contrast to the pictographic writing of China, changed the way of thinking since its invention a few thousand years ago, medievalists of the 1980s and 1990s discussed how the use of the already implemented writing and its application beyond the religious field changed between the eighth and fifteenth centuries. Research, with all differences in details, seemed to agree that writing now used for the political and legal organization of cities, the administration of property or in commerce - the use of feather and parchment or paper - took on a different meaning. With literacy spreading to these mundane purposes, society seemed to turn to more rational ways of dealing with life, shifting 'from sacred script to practical literacy'. ${ }^{20}$ In the same way, Hagen Keller emphasized that Western medieval society with its book religion was more book- and scripture-centred than antiquity. Nevertheless, it was only from the eleventh and twelfth centuries onward that city-dwellers as well as monks and noblemen organized their everyday life with writing, now increasingly using charters and registers and 'inventing' new types of account books and notarial documents. ${ }^{21}$ Without being prominent in the debates, the arguments somewhat echo Max Weber's claim of rational bureaucracy as a hallmark of the modern state and modernity in general; anyway, the overall perspective was certainly to detect the roots of our time in an epoch before the printing press.

It is far too easy to simply denounce this as a teleological or functional approach, because the great efforts and achievements made by this research cannot be questioned. The information gathered and presented provides a view on a (mostly) High 
and Late medieval society, in which in every field writing played an important role, even though movable types were not yet in use and even though most people were still illiterate. Therefore, if one were not to agree that we can see modernity in the making with the spread of the use of writing in the eleventh and twelfth centuries, the question is whether the use of writing might have served different purposes during the High and Late Middle Ages as presumed.

A great part of the articles and books on medieval literacy feed from the presumption of a divide between the oral and the written word, and that this would hold true for all epochs. Even if one looks at the simple act of reading silently or aloud, differences between the epochs are greater than the similarities. In contrast to today, practical literature, be it 'commercial' letters, charters or even account books, were read aloud most of the time ${ }^{22}$ until the sixteenth or seventeenth centuries. Even in fifteenth-century central Europe, despite a long tradition of written statutes, legal norms were more often deduced from (ad-hoc-invented) oral traditions than from written statutes. ${ }^{23}$

These findings coincide with the second paradigm which portrays premodern society as one that relies on the co-presence of actors. Writing, when applied by such society and embedded in such culture, adopts a different meaning and is assigned a different place in communication. Rather than being considered as an 'institution', ${ }^{24}$ highly independent from the given situation it is employed for, and even from the people that use it (as today generally is the case), writing in premodern times can be seen as an intrinsic part of the gatherings and meetings it is applied to. Writing may have been a tool for rationalization; it is also true that many texts were closely revised and commented on with marginal notes or glosses. However, more than that, it was an instrument to shape and enhance communication as such. Just one example: when administrators in fifteenth-century Switzerland, as Simon Teuscher explored, recorded what the people of a village told them about the (presumably) old rights of their lords, the scribes increasingly tended to use pseudo-archaic, presumably peasant-like language to describe 'old' rituals that would accompany the pay of duties. The purpose of the document is to look at both the way the text came to be as well as the content part of communication that takes place in assembly-like situations. This goes hand in hand with the observation that the materiality of a charter and its presentation was often more interesting (and convincing) than the content of the document. ${ }^{25}$

\section{Waiting for the postman: orality, literacy and messengers}

Messengers in the Middle Ages, similar to today, carried letters from sender to recipient. But, unlike today, the letter often worked more like a passport to identify and authorize the messenger, who then delivered the decisive information orally. Sometimes, on the other hand, the messenger's status underlined the importance of the written text and contributed to its interpretation. All three, the spoken word of the messenger, the messenger as a person and the writing, seem to feed from each other, and seemed to be engaged in a flexible but nevertheless unresolvable relationship, and sender and recipient had to be aware of this. ${ }^{26}$ The postman as someone who simply 
delivers a letter and does not influence the way the text of the letter is to be understood was yet to come.

One example of Late Medieval Cologne may illustrate how these more abstract considerations may help to understand what sources describe. When dealing with a defiant citizen in the fourteenth century, the Cologne city council would ask a number of councilmen (called 'Schickung') - generally two - to visit the insubordinate and urge him to behave properly. If these returned without success, the council would send out a second 'Schickung' and increase the number of councilmen, sometimes decisively. After all, in a pars-pro-toto situation, in the premodern sense of the word in nuce, the 'Schickung' represents the council as a whole. ${ }^{27}$ During the fifteenth century, the way in which the council communicated with its citizens changed: in 1469, the Cologne council ordered two of its members to urge Lenart Engelbrecht to stop suing a fellow citizen at an ecclesiastical court. If he would not obey, the order demanded that the two men should read out the respective law to Lenart aloud. The next (and last) step was to revoke his citizenship. ${ }^{28}$ While the text read aloud probably did not provide new information to someone who, like Lenart, knew how to manoeuvre between the different courts of fifteenth-century Cologne, reading meant that the 'speech' of the councilmen would become more impersonal. At the same time, the text read aloud represented the city council better than an increased number of councilmen, thus making the absent present. ${ }^{29}$

The scene may seem a slightly atypical, since it is a group of councilmen 'transforming' into messengers. Nevertheless, it proves to be very typical because, to understand what the 'message' is really about, the situation as a whole and the 'relationship' between all 'players' (orality, written text, persons, the location where all this took place) has to be taken into account. The hidden question behind these efforts was how to communicate even difficult matters by minimizing the risk of (violent) escalation and harming the parties involved.

\section{Writing down rituals}

Today, journalists and the public are trained to observe not only what political leaders and CEOs of important companies say, but also the gestures that accompany their statements. Did the presidents of two given nations shake hands, and how intense was that handshake? Did they smile, put on a grim face or not even look at each other? The public, being excluded from intimate conversations between world leaders and having a distrust in the all-too-well-known wording of press conferences, try to learn what is really going on by interpreting gestures - and politicians, being well aware of this, play that instrument quite well.

At first glance, gestures seem to be a timeless phenomenon, but the difference between their modern and premodern significance could not be greater. Today, gestures are looked at as signs that need to be read and interpreted to understand their meaning, a meaning the sign points to but is distinct from. In contrast to this, a premodern sitting order or who is given precedence to whom when entering a church not only displays who is closest to a duke or king or who knows how to behave properly. ${ }^{30}$ Rather, such 'moves' do not demonstrate, but create and define, the positions 
of the given person in the order of society as such, thus holding almost constitutional status. ${ }^{31}$ In this respect, it is no surprise that the Golden Bull of 1356, as mentioned above, dedicated a considerable number of its pages to how the prince-electors are seated and who would have to give the first vote. ${ }^{32}$ Gestures are written down because they themselves carry the meaning, ${ }^{33}$ and because they themselves create order. Rituals and gestures that produce meaning are, of course, not absent in modern society (as Austin and Searl already pointed out ${ }^{34}$ ). However, premodern society seems to be built almost entirely on performances, because (a) as mentioned above, it favours the co-presence of the actors and conceptualized signs and media in a different way; and (b) as a society that clearly distinguishes between different groups and statuses ${ }^{35}$ (instead of roles and classes), the changes of membership or status are accompanied by rituals.

But what are rituals anyhow? It seems worthwhile to remember some classical definitions, because they are still relevant as underlying presumptions for the analysis of sources and their meaning (although not always made explicit). There are at least four important perspectives on rituals that can be named:

(1) A descriptive approach portrays rituals as solemn ostentatious acts, which are often combined with certain gestures and special clothing.

The three other approaches are more functionalistic:

(2) Rituals demonstrate and emphasize a fact to a (mostly illiterate) public that otherwise would be difficult to bring across. In this respect, rituals are somewhat like a play, and the spread of writing and schooling would work against rituals. ${ }^{36}$

(3) With the (at least intended) participation of all people of a given entity (like city-dwellers who participate in a procession), rituals may foster or establish the identity of a given community. ${ }^{37}$

(4) Rituals are capable of changing the status of a person - which often goes hand in hand with a change of clothes (see definition 1). ${ }^{38}$ Needless to say, speech acts, as described above, suit this image well and can be considered part of such rituals.

It goes without saying that the different approaches named here rarely appear in their pure forms (for instance, the coronation of a king is a solemn act that changes the status of the person and increases the identity of the nobility and society as such). However, it is worthwhile to bear in mind the differences in order to see upon which a certain ritual (or better, the report of a certain ritual) lays its emphasis.

Since the early nineteenth century, historical and especially legal history ${ }^{39}$ took an interest in medieval rituals and their meanings. In 1990, Jean-Claude Schmitt clarified the importance of gestures and ritualized acts during the Middle Ages in his book La raison des gestes dans l'Occident medieval. ${ }^{40}$ His influential study covered the time from late antiquity until the thirteenth century. What is more, Jean-Claude Schmitt looked at reflections on gestures in medieval texts as well as 'practical' implementations of ritual acts. On the one hand, his main thread was to 'read' the gestures as a language of their own that has to be deciphered, and, combined with this, to see 
them as theatre-like performances that try to emphasize certain things. While La raison des gestes addresses specific movements of the body and with that rituals, focusing strongly on the religious sphere, Geoffrey Koziol's Begging Pardon and Favor (1992), in contrast, sees rituals as a general basis of political order, but limits his findings to northern France in the tenth and eleventh centuries. ${ }^{41}$ Nevertheless, his study already pointed the way to a new understanding of these acts.

During the late 1990s and the early years of the new millennium, premodern research on rituals and symbolic communication, as it was now often called, flourished especially in the German-speaking countries. In Konstanz (speaker: Rudolf Schlögl), Heidelberg (speakers: Axel Michaels, Bernd Schneidmüller) and Münster (speakers: Gerd Althoff, Barbara Stollberg-Rilinger), a great number of researchers worked together in these three different 'Collaborative Research Units', who dealt with that problem. Probably the most prominent has been the Münster Unit, named 'Symbolic Communication and Social Value Systems from the Middle Ages to the French Revolution', and the theoretical frame given at the beginning is not by accident inspired by the research done here. ${ }^{42}$ Besides a great number of interesting studies on specific phenomena, two main ideas guided the research especially of the Münster group:

(1) Rituals cannot be attributed to extra-rational behaviour and they do not document a premodern mentality. Rather, the persons involved negotiated (in a quite rational way) how in a given situation a ritual should be performed, and what it should mean and express.

(2) Rituals do not just show what has been agreed upon (i.e. written down in charters). Rather, they create and put into place new relationships and new orders. They are, in other words, the cornerstones of the 'constitution' medieval society is built on. ${ }^{43}$

This research dissolved the once strong dichotomy between literacy as rational, and with it the growing literacy as a sign that a society is on the way to modernity on the one hand, and orality, and with it rituals as a sign of a premodern mentality, on the other. What is more: since the 1990s, some doubts concerning the link between administrative 'rationality' and 'writing' emerged, ${ }^{44}$ because literacy now was increasingly seen as part of symbolic and ritualistic performances, and precisely this 'togetherness' of writing and ritual was considered a hallmark of premodern societies. ${ }^{45}$

\section{Communities, identity and performances}

The lack of centralized administration in the Middle Ages, a professional army or even a police force that deserves the name invites us to look for the famous 'glue' that would hold society together. Even modern states make use of ritualized acts, be it the inauguration ceremony of a president or a military parade, to foster identity. Medieval sources, legal texts included, every now and then describe gatherings and processions, the entry of a bishop in his city or the advent of a king as acts that meet similar requirements. More importantly, they seem to follow sometimes strange, although 
readable 'scripts' that provide identity for the communities involved; these acts also inform us about power relations between the protagonists.

Since the works of Simon Teuscher, we see a 'handle with care' stamp on at least some of these sources. Teuscher discovered that presumably very old legal rituals described in fifteenth-century sources are more a kind of late medieval 'invention of tradition' instead of native peasant (or Germanic) ways of doing justice. ${ }^{46} \mathrm{Nev}-$ ertheless, there is no question that the above-mentioned performances were very prominent in medieval society. This holds true for processions and the cult of city saints, the adventus as well as imperial diets. While the aspects of performing a kind of 'constitution' through rituals has already been discussed (establishing hierarchies and power relations), building 'identity' is another major viewpoint.

As far as can be seen, urban historians are those who have most intensively looked at different features that fostered the identification of city-dwellers with the town in which they live. ${ }^{47}$ Especially processions, which required the (sometimes forced) participation of all or most of its inhabitants, as well as - often combined with processions - the cult of city saints, are seen as public gatherings that aim to establish unity. But performances go far beyond religious festivities in the narrow sense of the word. Collective swearing of citizens' oath, elections or even legal proceedings when 'designed' in a performative way - are considered as means of creating an urban identity. Such gatherings - with great differences - can be observed in most western European cities during the Late Middle Ages, be it Nurnberg, London, Paris, Milan or Florence. ${ }^{48}$

To determine the problem and the 'solution' offered by performances, the 'unity' of a medieval city was nothing one could expect in the first place. 'The task for the late medieval and early modern cities was to transubstantiate these disparate characteristics of a community into a mystic body, a mystified city', as Edward Muir highlights in his classic study. ${ }^{49}$ Even more important, the walls of medieval cities regularly embraced a number of more or less independent communities (be these groups organized in city quarters or rather 'subtowns' or guilds), with Prague, Luzern but also Paris the most important examples, among many others. ${ }^{50}$

One of the most striking examples is the northern medium-sized German city of Braunschweig, whose five quarters had their own councils and even town halls. Each year, several processions took place in the northern German city of Braunschweig (an important member of the Hanseatic League). During one of such events, 12 members of the councils carried the remains of the Braunschweig city Saint, the holy Auctor, in his silver and golden shrine through the streets of the town, followed by all the citizens. With such processions, the otherwise socially and administratively strongly divided city presumably gained unity and identity. ${ }^{51}$ The core features of these performances are that (a) through the participation of all in these ritualized acts, individuals regarded themselves as part of a community. This is not by accident combined with (b) a religious dimension of these performances, especially when a saint (meaning the real Lord of the city) is addressed, who (c) through these performances is requested to support the city in various ways. ${ }^{52}$

However, one should not overlook that 'community' is, in the end, a very modern concept that obtained its contours mostly during the nineteenth century in opposite to 'society'. ${ }^{53}$ A closer look at urban rituals may well conclude that 
these processions and gatherings do not so much foster 'community'. Rather, they establish a hierarchical order between independent groups by especially emphasizing precisely this: the independence of these groups.$^{54}$ In this respect, urban performances would be more closely related to the establishment of premodern forms of constitution, as Barbara Stollberg-Rilinger clearly showed in respect of late medieval and early modern imperial diets. ${ }^{55}$ Either way, research agrees on the importance of performances as well as their specific otherness in the context of premodern society.

\section{Summary}

One of the fundamental insights offered to us by Reinhard Koselleck was that words and concepts, although they may look the same, changed their meanings completely between modern and premodern times. The same seems to be true for gestures, rituals and even literacy. In this other societal environment, the texts, gestures and performances occupy other places of meaning. Sometimes together - in different combinations - sometimes separately, the relationship of the named elements to the co-presence of persons is as essential as the idea that all people present participated in these acts, instead of just watching them. This does not mean that everybody present understood a certain ritual or a certain text, read out in public. But what members of this culture certainly share is a concept of communication that does not distinguish between (quasi-meaningless) ceremonies and 'real' written-down agreements as the only basis of court cases.

To take this observation a step further: as theory suggests, communication has (at least) two sides: an informational and a social (or, in other words, one can distinguish between information and utterance) ${ }^{56}$ It seems that greater emphasis is placed on the social aspect of communication in premodern times. One reason is probably that this culture largely insists on the co-presence of actors; another that the hierarchical order of society can hardly be ignored in any space or placed in the second row. The striking sensitivity of premodern societies in terms of ritualized acts, or of the way texts are read aloud, and with it the possibility that meetings and gatherings may suddenly lead to (even violent) escalations, is thus not so much rooted in a certain mentality, but in a certain culture of communication.

\section{Notes}

1 M. McLuhan, The Gutenberg Galaxy: The Making of Typographic Man, Toronto: University of Toronto Press, 1962; Ibid., Die Gutenberg-Galaxis: das Ende des Buchzeitalters, Bonn u.a.: Addison-Wesley, 1995.

2 J. Goody, The Domestication of the Savage Mind, Cambridge: Cambridge University Press, 1977; J.-W. Goody, I. Watt, 'The Consequences of Literacy', Comparative Studies in Society and History 5, 1963, 304-45; W.J. Ong, Orality and Literacy: The Technologizing of the Word, London: Methuen, 1982.

3 J. Grimm, Deutsche Rechtsalterthümer, 2 vols, Leipzig: Mayer \& Müller, 1922.

4 J.L. Austin, How to Do Things with Words, Oxford: Clarendon Press, 1963, based on a lecture delivered in 1955; E. Goffman, Behavior in Public Places: Notes on the Social Organization of Gatherings, New York: Free Press of Glencoe, 1963. 
5 B. Schneidmüller, 'Inszenierungen und Rituale des spätmittelalterlichen Reichs. Die Goldene Bulle von 1356 in westeuropäischen Vergleichen', in U. Hohensee et al. (eds), Die Goldene Bulle Kaiser Karls IV. Politik - Wahrnehmung - Rezeption, Berlin: Akad.-Verl., 2009, 269ff.; G. Schwedler, 'Dienen muss man dürfen oder: Die Zeremonialvorschriften der Goldenen Bulle zum Krönungsmahl des römisch-deutschen Herrschers', in C. Ambos et al. (eds), Die Welt der Rituale. Von der Antike bis heute, Darmstadt: Wissenschaftliche Buchgesellschaft, 2005, 159ff.

6 The terms are coined by Rudolf Schlögl (Vergesellschaftung unter Anwesenden) and Barbara Stollberg-Rilinger (Präsenzgesellschaft). While there are differences between the two concepts, they are both based on the systems theory of Niklas Luhmann, and they both point in the same direction - and that is of interest here; R. Schlögl, 'Kommunikation und Vergesellschaftung unter Anwesenden. Formen des Sozialen und ihre Transformation in der Frühen Neuzeit', Geschichte und Gesellschaft 34, 2, 2008, 171ff.; B. Stollberg-Rilinger, Des Kaisers alte Kleider. Verfassungsgeschichte und Symbolsprache des Alten Reiches, München: C. H. Beck, 2008, 299 ff and 310f.

7 Ibid., Des Kaisers alte Kleider.

8 'Wort und Bild sind Medien der Repräsentation, des Gegenwärtig-Werden-Lassens, In-die-Gegenwart-Rufens von etwas, das abwesend ist (lokaler Aspekt) oder vergangen (temporaler Aspekt)'; H. Wenzel, Hören und Sehen, Schrift und Bild. Kultur und Gedächtnis im Mittelalter, München: Beck, 1995, 306.

9 C. Kiening, 'Mediale Gegenwärtigkeit. Paradigmen - Semantiken - Effekte', in Ibid. (ed.), Mediale Gegenwärtigkeit, Zürich: Chronos, 2007, 19f.: 'Premodern times add an ontological understanding of the sign, a juridically binding of representation, an iconic of the image, and an auratic understanding of writing etc. Recent medieval research has taught us: gestures, rituals, ostentations, documents, seals and objects, images, sculptures and buildings did not only serve as means to transmit or store information or as means of communication. They also, and even more than that, served to make the absentee present, to establish aura, to transmit salvation ... This in turn can mean: With the Middle Ages, a certain "culture of presence" comes into view, which would allow us to observe what was before the modern "culture of sense" and which, for this modern one, is hard to describe and to categorize' (author's translation).

10 Ibid., 20.

11 W.J. Ong, Orality and Literacy; J. Goody, Domestication; J.-W. Goody, I. Watt, 'The Consequences of Literacy', 344f.

12 E.L. Eisenstein, The Printing Revolution in Early Modern Europe, Cambridge et al.: Cambridge University Press, 1983.

13 Both Ong and Eisenstein highlight the importance of tables and lists; Ibid., 63; W.J. Ong, Oralität und Literalität. Die Technologisierung des Wortes, Opladen: Westdeutscher Verlag, 1987, 102.

14 In Münster, an interdisciplinary Collaborative Research Center (Sonderforschungsbereiche), led by Hagen Keller and Christel Meier, worked for more than 12 years on literacy in the Middle Ages; C. Meier et al. (eds), Pragmatische Dimensionen mittelalterlicher Schriftkultur. Akten des Internationalen Kolloquiums des Sonderforschungsbereichs 231 26.-29. Mai 1999, München: Wilhelm Fink, 2002; C. Meier, 'Vierzehn Jahre Münsteraner Forschung zur Schriftlichkeit im Mittelalter. Die Arbeit des Sonderforschungsbereichs 231, Träger, Felder, Formen pragmatischer Schriftlichkeit im Mittelalter', in F.-J. Arlinghaus et al. (eds), Beitrag auf der CD-ROM Schrift im Wandel - Wandel durch Schrift, Turnhout: Brepols 2004. The Collaborative Research Center of Freiburg im Breisgau, led by Wolfgang Raible, was not limited to the Middle Ages; see H. Günther and O. Ludwig (eds), Schrift und Schriftlichkeit/Writing and Its Use. Ein interdisziplinäres Handbuch 
internationaler Forschung/An Interdisciplinary Handbook of International Research 1, Berlin, New York: De Gruyter 1994, and the various books published in the 'ScirptOralia', Gunter Narr Publisher, Tübingen. Rogier Sablonier and Simon Teuscher and their team worked in Zürich on that theme; R. Sablonier and S. Teuscher, Schriftlichkeit, Kommunikationskultur und Herrschaftspraktiken im Spätmittelalter. Forschungsprojekt am Historischen Seminar der Universität Zürich, Zürich: no publisher, 1996. Marco Mostert and his team worked in Utrecht, the Netherlands, on literacy in the Middle Ages. See the series 'Utrecht Studies in Medieval Literacy', Brepols publishers, Turnhout. For Zürich see R. Sablonier, 'Verschriftlichung und Herrschaftspraxis. Urbariales Schriftgut im spätmittelalterlichen Gebrauch', in C. Meier et al. (eds), Pragmatische Dimensionen mittelalterlicher Schriftkultur. Akten des Internationalen Kolloquiums des Sonderforschungsbereichs 231, 26.-29. Mai 1999, München: Wilhelm Fink 2002, 91ff., and S. Teuscher, 'Notiz, Weisung, Glosse. Zur Entstehung "mündlicher Rechtstexte" im spätmittelalterlichen Lausanne', in U. Kleine and L. Kuchenbuch (eds), Textus?, Göttingen: Vandenhoeck \& Ruprecht, 2006, 253ff.

15 The inspiring study of R. McKitterick, The Carolingians and the Written Word, Cambridge, UK: Cambridge University Press, 1989, argues that one should not overlook the prominence of writing already during the eighth and ninth centuries. But as far as one can see, for major and profound changes, historical research looks more at the High Middle Ages than at the Carolingian period.

16 Ibid.

17 On Italian notaries see P. Schulte, Scripturae publicae creditur. Das Vertrauen in Notariatsurkunden im kommunalen Italien des 12. und 13. Jahrhunderts, Tübingen: Niemeyer, 2003.

18 H. Keller, 'Über den Zusammenhang von Verschriftlichung, kognitiver Orientierung und Individualisierung. Zum Verhalten italienischer Stadtbürger im Duecento', in C. Meier et al. (eds), Pragmatische Dimensionen mittelalterlicher Schriftkultur. Akten des Internationalen Kolloquiums des Sonderforschungsbereichs 231, 26.-29. Mai 1999, München: Wilhelm Fink, 2002, 1ff.

19 For instance, E.A. Havelock, The Literate Revolution in Greece and Its Cultural Consequences, Princeton NJ: University Press, 1982.

20 M.T. Clanchy, From Memory to Written Record: England 1066-1307, Oxford: Blackwell Publishing, 1993, 333.

21 H. Keller, "Vom "heiligen Buch" zur "Buchführung" - Lebensfunktionen der Schrift im Mittelalter', Frühmittelalterliche Studien 26, 1992, 1-31.

22 R. Schlögl, 'Kommunikation unter Anwesenden', 194; already M.T. Clanchy, From Memory to Written Record, 195, 271, 278. P.H. Saenger, Space Between Words: The Origins of Silent Reading, Stanford, CA: Stanford University Press, 1997, makes clear that silent reading was a novelty in High and Late Medieval Europe.

23 S. Teuscher, Erzähltes Recht. Lokale Herrschaft, Verschriftlichung und Traditionsbildung im Spätmittelalter, Frankfurt/M., New York: Campus Verlag, 2007, 313.

24 I owe this term to a discussion with Rudolf Schlögl.

25 S. Teuscher, Erzähltes Recht, 312 and $260 \mathrm{ff}$.

26 See the classical study of H. Wenzel, Hören und Sehen, 253ff.; R. Köhn, 'Latein und Volkssprache, Schriftlichkeit und Mündlichkeit in der Korrespondenz des lateinischen Mittelalters', in G.O. Fichte (ed.), Zusammenhänge, Einflüsse, Wirkungen. Kongreßakten zum ersten Symposion des Mediävistenverbandens in Tübingen, Berlin: De Gruyter, 1986, 340; M. Jucker, Gesandte, Schreiber, Akten. Politische Kommunikation auf eidgenössischen Tagsatzungen im Spätmittelalter, Zürich: Chronos, 2004, 80f.; in regard to the investiture controversy: T. Wetzstein, 'Von der Unmöglichkeit zu kommunizieren. Briefe, Boten 
und Kommunikation im Investiturstreit', in F. Hartmann (ed.), Brief und Kommunikation im Wandel, Köln, Weimar, Wien: Böhlau, 2016, 43ff.

27 M. Groten, 'Im glückseligen Regiment. Beobachtungen zum Verhältnis Obrigkeit Bürger am Beispiel Kölns im 15. Jahrhundert', Historisches Jahrbuch 116, 1996, 307. On premodern representation as pars-pro-toto see H. Hofmann, Repräsentation: Studien zur Wort- und Begriffsgeschichte von der Antike bis ins 19. Jahrhundert, Berlin: Duncker \& Humblot, 2003.

28 HAStK, Rm 10-2, fol. 122r, 05.07.1469; a regesta gives Beschlüsse des Rates der Stadt Köln 1320-1550, vol. 1: Die Ratsmemoriale und ergänzende Überlieferung 1320-1543 (Publikationen der Gesellschaft für Rheinische Geschichtskunde 65), ed. by Manfred Huiskes, Düsseldorf: Droste, 1990, no. 1469/26, 366f.; see F.-J. Arlinghaus, Inklusion - Exklusion. Funktion und Formen des Rechts in der spätmittelalterlichen Stadt. Das Beispiel Köln, Wien, Köln, Weimar: Böhlau, 2018, 298ff.

29 Ibid., 298ff.

30 K.-H. Spieß, 'Rangdenken und Rangstreit im Mittelalter', in W. Paravicini (ed.), Zeremoniell und Raum, Sigmaringen: Jan Thorbecke, 1997, 39ff.

31 B. Stollberg-Rilinger, 'Zeremoniell, Ritual, Symbol. Neuere Forschungen zur symbolischen Kommunikation in Spätmittelalter und Früher Neuzeit', Zeitschrift für historische Forschung 27, 2000, 389.

32 J. Rogge, Die deutschen Könige im Mittelalter. Wahl und Krönung, Darmstadt: Wiss. Buchges., 2006.

33 One of the first studies to pave the way on looking at gestures and rituals was Jean-Claude Schmitt: J.-C. Schmitt, La raison des gestes dans l'Occident médiéval, Paris: Gallimard, 1990.

34 J.L. Austin, How to Do Things with Words, Oxford: Harvard University Press, 1977; U. Wirth, 'Der Performanzbegriff im Spannungsfeld von Illokution, Iteration und Indexikalität', in ibid. (ed), Performanz. Zwischen Sprachphilosophie und Kulturwissenschaften, Frankfurt/M.: Suhrkamp, 2002, 9ff.

35 See K. v. Greyerz, Passagen und Stationen. Lebensstufen zwischen Mittelalter und Moderne, Göttingen: Vandenhoeck \& Ruprecht, 2010.

36 See J.-C. Schmitt, La raison des gestes.

37 The central concept goes back to Émile Durkheim: 'Voilâ donc tout un ensemble de cérémonies qui se proposent uniquement de réveiller certaines idées et certains sentiments, de rattacher le present au passé, l'individu à la collectivité'; É. Durkheim, Les formes élémentaires de la vie religieuse. Le système totémique en Australie, Paris: Félix Alcan, 1912, 541.

38 The classical study is that of A. van Gennep, Les rites de passage, Paris: Editions A. Et J. Picard, 1981, 2nd edn. K. v. Greyerz, Passagen und Stationen, seems to lean on this.

39 See for instance J. Grimm, Deutsche Rechtsalterthümer.

40 J.-C. Schmitt, La raison des gestes.

41 G. Koziol, Begging Pardon and Favor: Ritual and Political Order in Early Medieval France, Ithaca, NY, London: Cornell University Press 1992.

42 Konstanz: https://cms.uni-konstanz.de/fileadmin/archive/sfb485/index.html (last visited August 2018); see: R. Schlögl, B. Giesen and J. Osterhammel (eds), Die Wirklichkeit der Symbole. Grundlagen der Kommunikation in historischen und gegenwärtigen Gesellschaften, Konstanz: UVK Verl.-Ges., 2004; Heidelberg: www.ritualdynamik.de/index. php?id=1\&L=1 (last visited August 2018); see M. Steinicke and S. Weinfurter (eds), Investitur- und Krönungsrituale. Herrschaftseinsetzungen im kulturellen Vergleich, Köln et al.: Böhlau, 2005. 
43 Münster: www.uni-muenster.de/SFB496/Welcome-e.html (last visited August 2018); see G. Althoff, Die Macht der Rituale. Symbolik und Herrschaft im Mittelalter, Darmstadt: Primus, 2003; B. Stollberg-Rilinger, 'Symbolische Kommunikation in der Vormoderne. Begriffe - Thesen - Forschungsperspektiven', Zeitschrift für Historische Forschung 31, 2004, 489ff.

44 A concrete example gives S. Teuscher, Erzähltes Recht, 265f. See in respect of double-entry bookkeeping F.-J. Arlinghaus, Zwischen Notiz und Bilanz. Zur Eigendynamik des Schriftgebrauchs in der kaufmännischen Buchführung am Beispiel der Datini/di BertoHandelsgesellschaft in Avignon (1367-1373), Frankfurt/M.: Peter Lang, 2000.

45 H. Keller and C. Dartmann, 'Inszenierungen von Ordnung und Konsens. Privileg und Statutenbuch in der symbolischen Kommunikation mittelalterlicher Rechtsgemeinschaften', in G. Althoff (ed.), Zeichen - Rituale - Werte. Internationales Kolloquium des Sonderforschungsbereichs 496 an der Westfälischen Wilhelms-Universität Münster, Münster: Rhema, 2004, 201ff., see R. Schlögl, Anwesende und Abwesende. Grundriss für eine Gesellschaftsgeschichte der Frühen Neuzeit, Konstanz: Konstanz University Press, 2014, $160 f$.

46 S. Teuscher, Erzähltes Recht.

47 See the excellent study of B.A. Hanawalt (ed.), City and Spectacle in Medieval Europe, Minneapolis, MN et al.: Univ. of Minnesota Press, 1994, who put ceremonies and rituals in a broader context.

48 The path-breaking study is still R.C. Trexler, Public Life in Renaissance Florence, New York: Cornell Univ. Press, 1980; A. Löther, Prozessionen in spätmittelalterlichen Städten. Politische Partizipation, obrigkeitliche Inszenierung, städtische Einheit, Köln, Weimar, Wien: Böhlau, 1999; Recently B.A. Hanawalt, Ceremony and Civility. Civic Culture in Late Medieval London, Oxford: Oxford Univ. Press, 2017 (with literature); E.A.R. Brown and N. Freeman Regalado, 'Universitas et communitas: The Parade of the Parisians at the Pentecost Feast of 1313', in K. Ashley and W. Hüsken (eds), Moving Subjects: Processional Performance in the Middle Ages and the Renaissance, Amsterdam, Atlanta: Rodopi, 2001; C. Dartmann, Politische Interaktion in der italienischen Stadtkommune. 11.-14. Jahrhundert, Ostfildern: Jan Thorbecke, 2012.

49 E. Muir, Ritual in Early Modern Europe, Cambridge: Cambridge Univ. Press, 1997, 233.

50 For a general discussion see J. Rogge, 'Viertel, Bauer, Nachbarschaften. Bemerkungen zu Gliederung und Funktion des Stadtraumes im 15. Jahrhundert (am Beispiel von Braunschweig, Halberstadt, Halle und Hildesheim)', in M. Puhle (ed.), Hanse Städte - Bünde. Die sächsischen Städte zwischen Elbe und Weser um 1500. Ausstellungskatalog, Magdeburg: Kulturhistorisches Museum Magdeburg, 1996, 231ff. For Prague L. Belzyt, "Sondergemeinden" in Städten Ostmitteleuropas im 15. und 16. Jahrhundert am Beispiel von Prag, Krakau und Lemberg', in P. Johanek (ed.), Sondergemeinden und Sonderbezirke in der Stadt der Vormoderne, Köln, Weimar: Böhlau, 2004, 165ff.; Lucerne: C. Thévenaz-Modestin, Un mariage contesté. L'union de la Cité et la Ville inférieure de Lausanne (1481), Lausanne: Université de Lausanne, 2006; J. Oberste, Die Geburt der Metropole. Städtische Räume und soziale Praktiken im mittelalterlichen Paris, Regensburg: Schnell + Steiner, 2018.

51 U. Israel, 'Die Stadt und ihr Patron. Konstituierung und Stabilisierung sozialer Ordnung im europäischen Mittelalter am Beispiel Braunschweigs', Zeitschrift für Kirchengeschichte 122, no. 4, 60, 2011, 173ff. (with an abstract in English and further literature).

52 'Ein sakrales Ritual besteht im Kern darin, dass die Handelnden durch den Vollzug normierter, symbolisch aufgeladener Formen das Eingreifen einer transzendenten 
Macht provozieren und auf diese Weise eine gewünschte Wirkung herbeiführen'; B. Stollberg-Rilinger, Des Kaisers alte Kleider, 95.

53 L. Gertenbach et al. (eds), Theorien der Gemeinschaft zur Einführung, Hamburg: Junius, 2010.

54 F.-J. Arlinghaus, 'The Myth of Urban Unity: Religion and Social Performance in Late Medieval Braunschweig', in C. Goodson, A. E. Lester and C. Symes (eds), Cities, Texts, and Social Networks, 400-1500: Experiences and Perceptions of Medieval Urban Space, Farnham, Burlington, VT: Ashgate, 2010, 215ff.

55 B. Stollberg-Rilinger, Des Kaisers alte Kleider, 17f.

56 Communication as a process distinguishes between information and utterance and [has] to indicate which side of the distinction is supposed to serve as the base for further communication'; N. Luhmann, 'The Autopoiesis of Social Systems', in F. Geyer and J. von der Zouwen (eds), Socicybernetic Paradoxes. Observation, Control and Evolution of Self-Steering Systems, London: SAGE Publications, 1986, 4; Ibid., Social Systems, Translated by John Bednarz, Jr., with Dirk Baecker, Stanford, CA: Stanford Univ. Press, 1995, $139 f f$. 